\title{
Improving the Criminal Law Protection of Relations in the Field of the Digital Economy from Crime Assaults
}

\author{
Kulikova A.A. \\ Institute of Service Sector and Entrepreneurship (Branch) of the Don State Technical University in Shakhty (ISS\&E \\ (Branch) of the DSTU in Shakhty) Shakhty, Russia \\ naukatgp@yandex.ru
}

\begin{abstract}
Within the framework of the implementation of the Decree of the President of the Russian Federation No.204 dated May 7, 2018, "On National Goals and Strategic Objectives of the Development of the Russian Federation for the Period until 2024," including with the aim of solving the problem of ensuring the accelerated introduction of digital technologies in the economy and social sphere, the Government of the Russian Federation, based on the program "Digital Economy of the Russian Federation," has formed the national program "Digital Economy of the Russian Federation" approved by the minutes of the meeting of the Presidium of the Council under the President of the Russian Federation on Strategic Development and National Projects No. 7 dated June 4, 2019.

Among the fields for the implementation of the national program "Digital Economy of the Russian Federation," "Statutory Regulation of the Digital environment" is defined. In this field, it is required to ensure the unhindered development of the digital economy, protected from criminal attacks. Criminal legal protection of public relations in the field of the digital economy requires urgent rapid development.

In this regard, within the framework of this paper, the results of the analysis of criminal assaults and criminal legal means of counteracting them will be presented. Based on the analysis, the paper will present developed recommendations on improving the criminal law protection of relations from criminal attacks in the field of the digital economy.
\end{abstract}

Keywords: digital economy, criminal law protection, digital crime, information

\section{INTRODUCTION}

The modern life of society and the state is closely connected with up-to-date information technologies. Information technologies are applied in all spheres of life of society and of a person. Through these technologies, citizens exercise their rights and obligations, new forms of providing public services via the Internet are being actively introduced, electronic payment services have been developed and implemented, the concept of an electronic document and electronic signature has been enshrined at the legislative level, etc.

Public relations arising in connection with the use of information technologies are at the stage of formation and active development, despite their wide distribution. Like any other things, they require a legislative regulation. The specificity of the relations under consideration is their application in various spheres of public life. Offenses related to the encroachment on the security of digital information encroach on such objects of legal protection as privacy, cashless funds, state, commercial, and other secrets, intellectual property rights, property, etc.
In Russia, the information society is characterized by the widespread and affordable availability of mobile devices (there are two mobile subscription numbers per Russian citizen on average), as well as wireless technologies and communication networks. A system for the provision of state and municipal services in electronic form, to which more than 34 million Russians have connected, has been created. Citizens obtained the opportunity to send individual and mass appeals to state bodies and local governments in electronic form.

Information and communication technologies have become part of modern management systems in all sectors of the economy, in the fields of public administration, national defense, state security, and law enforcement.

However, despite the widespread introduction of information technology in the life of society, the legal regulation of relations associated with them is fragmented. Within the framework of the implementation of the Decree of the President of the Russian Federation No. 204 dated May 7, 2018, "On National Goals and Strategic Objectives of the Development of the Russian Federation for the Period until 2024" [1], including with the aim of solving 
the problem of ensuring the accelerated introduction of digital technologies in the economy and social sphere, the Government of the Russian Federation, based on the program "Digital Economy of the Russian Federation," has formed the national program "Digital Economy of the Russian Federation" approved by the minutes of the meeting of the Presidium of the Council under the President of the Russian Federation on Strategic Development and National Projects No. 7 dated June 4, 2019 [2].

Among the fields for the implementation of the national program "Digital Economy of the Russian Federation," "Statutory Regulation of the Digital environment" is defined. In this field, it is required to ensure the unhindered development of the digital economy, protected from criminal attacks. Criminal legal protection of public relations in the field of the digital economy requires urgent rapid development.

Currently, there are no comprehensive studies in this field. Separate papers are devoted to criminal legal protection of copyrights [3], the most popular are studies in the field of combating crimes in the field of computer information. There are a large number of scientific publications and dissertation research in this field [4]. Some writings are devoted to the protection of digital law by criminal legal means as property law [5].

Foreign studies regarding the protection of digital rights to a greater extent emphasize the protection of copyright and related rights from criminal encroachments. Some studies are devoted to the investigation of virtual cybercrime, the grounds for criminalizing actions committed in the digital space, such as crimes related to child pornography, to violation of copyright and related rights, actions of a racist and xenophobic nature, etc., are being researched [6].

Our study focuses on changes in criminal law introduced in the section "Crimes in the Field of Economy."

\section{METHODOLOGY}

The methodological base of the research consists of general scientific methods, including dialectic, formal logic, analysis, and synthesis; private scientific methods, including logical-legal, comparative-legal, systemstructural, analysis of documents; sociological methods, including questionnaires, analysis of print and electronic publications, statistical methods.

\section{RESULTS OF THE RESEARCH}

Based on the analysis of criminal law aimed at protecting public relations in the digital economy, we came to the following conclusions.

The relevance of introducing Clause "d" of Part 3 of Article 158 of the Criminal Code of the Russian Federation [7] can hardly cause any doubts since, due to the active development of modern telecommunication technologies and the possibility of electronic payments, there is high growth in crimes related to the theft of funds from bank accounts and electronic Money. However, we believe that the public danger of the action in question is somewhat overstated. We propose to transfer the criminal action provided for by Clause "g" from Part 3 of Article 158 of the Criminal Code from the grave category to the category of medium-gravity crimes and place it in Part 2 of Article 158 of the Criminal Code.

To clarify the signs of a crime under the existing edition of Article 159.3 it is advisable to refer to the previous edition of this article and the decision of the Plenum of the Supreme Court of the Russian Federation. In this regard, we consider the new edition of Article 159.3 unsuccessful and subject to more detailed consolidation of the signs of the punishable action, particularly: "Fraud using electronic means of payment, that is, a theft of another person's property committed with the use of information and communication technologies, electronic storage media, including payment cards, as well as other technical devices, by deceiving an authorized employee of a credit, trade, or other organization, shall be punished ..."

\section{DISCUSSION OF RESULTS}

Criminal law protects the most important public relations from criminal attacks. To ensure the protection of the digital economy from criminal attacks, it is required, first of all, to determine the circle of social relations involved in the development of the digital economy. The concept of the "digital economy" is contained in the Decree of the President of the Russian Federation No. 203 dated 05/09/2017 "On the Strategy for the Development of the Information Society in the Russian Federation for 20172030" [8] and is defined as economic activity, in which digital data is a key factor in production and processing large volumes and using the results of an analysis of such data may significantly increase the efficiency of various types of production, technologies, equipment, storage, sales, delivery of goods and services, if compared with traditional forms of management. Accordingly, based on this definition, we may conclude that the distinguishing feature of relations in the digital economy is their "computerized," "informational" form.

In order to protect economic relations implemented using digital technologies, Section VIII "Crimes in the Field of Economics" of the Criminal Code of the Russian Federation was amended by Federal Law No.111-FZ dated 04/23/2018 [9]. Particularly, a qualifying attribute was introduced in Part 3 of Article 158 of the Criminal Code of the Russian Federation, providing for the responsibility for a theft from a bank account, as well as in relation to electronic money. The edition of Articles 159.3 and 159.6 was also updated. The changes cause conflicting feelings. Let us consider in more detail.

In accordance with the Federal Law No.161-FZ dated 06/27/2011 "On the National Payment System" [10], electronic cash is cash that has been previously provided by one person (the person who provided the funds) to another person that takes into account information about the amount of money provided without opening a bank account (the obligated person) in order to fulfill the 
monetary obligations of the person who provided the funds to third parties and in respect of which the person who provided the funds is entitled to transfer orders exclusively with the use of electronic means of payment. The relevance of introducing Clause " $d$ " of Part 3 of Article 158 of the Criminal Code of the Russian Federation can hardly cause any doubts since, due to the active development of modern telecommunication technologies and the possibility of electronic payments, there is high growth in crimes related to the theft of funds from bank accounts and electronic Money. However, we believe that the public danger of the action in question is somewhat overstated.

The mechanism of a theft from a bank account or electronic money makes it more responsible for committing it since it involves preliminary preparation for a crime, identification of means of overcoming bank protection, penetration into electronic systems, etc. Overcoming obstacles to the commission of crime indicates a higher degree of criminality of the offender, the planned nature of the theft, and the desire to achieve a criminal goal, despite obstacles.

But the legislator puts the action in question on a par with illegal intrusion into the home, theft from an oil pipeline, oil product pipeline, gas pipeline, and the theft on a large scale. At the same time, the amount of stolen funds from the bank account, as well as in relation to electronic money, is not indicated as a mandatory feature in qualifying this action.

A theft committed with intrusion into the home encroaches not only on the property of the victim but increases the risk of harm (including mental) to the life and health of the victim, as well as violates the right to inviolability of the home declared by the Constitution of the Russian Federation [11]. A theft committed with intrusion into the premises or other storage encroaches on the property of citizens or legal entities. Of course, we may say that intrusion into premises or storage also threatens the life and health of people, such as a watchman, a security guard, but the likelihood of them being in the premises or storage is lower than the probability of the presence of people in the home. Therefore, the legislator differentiated responsibility for a theft with intrusion into premises or other storage with a theft committed with intrusion into the home, imposing more severe punishment for the latter. If figuratively imagine the theft from a bank account, as well as in relation to electronic money, the overcoming of electronic protection by a criminal, then, in terms of the nature of the actions performed and the degree of public danger, this action will be more comparable to the theft committed with illegal intrusion into the premises or other storage than with penetration into the home.

We believe this state of affairs does not correspond to the principle of justice and the public danger of the action in question is overstated by the legislator. With regard to the aforesaid, we propose to transfer the criminal action provided for by Clause "d" from Part 3 of Article 158 of the Criminal Code from the grave category to the category of medium-gravity crimes and place it in Part 2 of Article 158 of the Criminal Code.

Federal Law No.111-FZ dated 04/23/2018 significantly transformed Article 159.3. The changes not only affected the method of committing fraud, i.e. from "using payment cards" to "using electronic means of payment," a description of the criminal action itself was radically transformed as well. If in the previous edition the disposition was descriptive and all the signs of a crime were indicated, then the updated version contains only an indication of the criminal activity itself, which raises a number of questions. First of all, what exact actions lead to the responsibility of the article under consideration?

An electronic means of payment is a means and (or) a method that allows a client of a money transfer operator to draw up, certify, and transfer orders with the purpose to transfer funds within the framework of the applicable forms of cashless payments using information and communication technologies, electronic storage media, including payment cards and other technical devices (Federal Law "On the National Payment System").

Fraud refers to the theft of another person's property or the acquisition of the right to another person's property through fraud or breach of trust. The Decree of the Plenum of the Supreme Court of the Russian Federation No. 48 dated 11/30/2017 "On Judicial Practice in Cases of Fraud, Misappropriation, and Embezzlement" [12] discloses the concept of fraud as a way of committing theft or acquiring the right to another person's property as a deliberate communication (provision) of knowingly false, untrue details, either omission of true facts or deliberate actions aimed at misleading the owner of the property or other person.

In the previous version of Article 159.3, fraud with the use of payment cards referred to the theft of another person's property committed using a fake or another person's credit card, settlement card, or another type of payment card by deceiving an authorized employee of a credit, trading, or other organization. That is, a mandatory sign of this type of fraud was a fraud of an authorized employee of a credit, trade, or other organization.

In connection with the amendments to the Criminal Code of the Russian Federation, we believe that the use of someone else's mobile phone to pay in a store by means of a contactless payment system will be qualified as fraud using electronic means of payment. Since in this case, the mechanism of the committed criminal action is similar to that described above.

Therefore, the question arises, how to qualify the action, when, for example, the offender also asked the victim for a phone to make a call and thereupon, paid for the goods or service on the Internet through a payment system? Indeed, in this case, deception is committed against the owner of the property but not an employee of a credit, trade, or other organization. The disposition of the new edition of Article 159.3 does not describe the signs of fraud using electronic means of payment, therefore, based on the definition of "fraud" and "electronic means of payment," formally, the 
po strategicheskomu razvitiyu i nacional'nym proektam, protokol ot 04.06.2019 No. 7) // https://digital.gov.ru

question.

The Decree of the Plenum of the Supreme Court of the Russian Federation No. 48 dated 11/30/2017 contains an indication that if the fraud is not aimed directly at taking possession of another person's property but it is used only to facilitate access to it, the actions of the perpetrator, depending on the method of theft, constitute a theft or robbery. Therefore, if we consider the example we have given, then the mobile phone, in this case, will be obtained by fraud to facilitate access to other people's electronic money because the purpose of the offender is not the mobile phone itself.

Thus, it follows that to clarify the signs of a crime under the existing edition of Article 159.3 it is advisable to refer to the previous edition of this article and the decision of the Plenum of the Supreme Court of the Russian Federation. In this regard, we consider the new edition of Article 159.3 unsuccessful and subject to more detailed consolidation of the signs of the punishable action, particularly: "Fraud using electronic means of payment, that is, a theft of another person's property committed with the use of information and communication technologies, electronic storage media, including payment cards, as well as other technical devices, by deceiving an authorized employee of a credit, trade, or other organization, shall be punished ..."

\section{CONCLUSIONS}

In conclusion, I would like to note that the Russian criminal legislation as a whole requires revision in connection with the digitalization of public relations everywhere in all spheres of society. Currently, there are no comprehensive studies of criminal legislation aimed at reforming the system of regulations providing criminal legal protection from criminal attacks on human rights and freedoms, property, honor, dignity, business reputation, intellectual property, and other property and non-property benefits protected by law in a digital environment. The legislator has made some attempts to introduce criminal legal means of combating crime in the field of the digital economy, however, in our opinion, this is not enough, and an integrated approach to solving the challenges facing the present day is required.

\section{REFERENCES}

[1] Ukaz Prezidenta RF ot 07.05.2018 No. 204 (red. ot 19.07.2018) «O nacional'nyh celyah i strategicheskih zadachah razvitiya Rossijskoj Federacii na period do 2024 goda» // Sobranie zakonodatel'stva RF. - 2018. No. 20. - St. 2817.

[2] «Pasport nacional'nogo proekta «Nacional'naya programma «Cifrovaya ekonomika Rossijskoj Federacii» (utv. prezidiumom Soveta pri Prezidente RF
[3] CHernyshov V.N., Kochetkova M.N. Ugolovnopravovaya ohrana avtorskih prav $\mathrm{v}$ seti Internet kak element obespecheniya bezopasnosti informacionnogo obshchestva // Sovremennoe pravo, 2018, No. 7-8

[4] Begishev I. R. Ponyatie i vidy prestuplenij v sfere obrashcheniya cifrovoj informacii : avtoreferat dissertacii na soiskanie uchenoj stepeni kandidata yuridicheskih nauk : special'nost' 12.00.08 / Begishev Il'dar Rustamovich ; [CHast. obrazovat. uchrezhdenie vyssh. obrazovaniya "Kazan. innovac. un-t im. V. G. Timiryasova"]. - Kazan', 2017. -31 s.

[5] Dolgieva M.M. Kriptoprestupnost' kak novyj vid prestupnosti: ponyatie, specifika // Sovremennoe pravo, 2018, No. 10

[6] Litska Strikwerda. When Should Virtual Cybercrime Be Broudht under the Scope of the Criminal Law?// Digital Forensics and Cyber Crime

[7] Ugolovnyj kodeks Rossijskoj Federacii ot 13.06.1996 No. 63-FZ (red. ot 18.02.2020) // Sobranie zakonodatel'stva RF. - 1996. - No. 25. - St. 2954.

[8] Ukaz Prezidenta RF ot 09.05.2017 No. $203 \ll \mathrm{O}$ Strategii razvitiya informacionnogo obshchestva $\mathrm{V}$ Rossijskoj Federacii na 2017 - 2030 gody» // http://www.pravo.gov.ru

[9] Federal'nyj zakon ot 23.04.2018 No. 111-FZ «O vnesenii izmenenij v Ugolovnyj kodeks Rossijskoj Federacii» // http://www.pravo.gov.ru

[10] Federal'nyj zakon ot 27.06.2011 No. 161-FZ (red. ot 27.12.2019) «O nacional'noj platezhnoj sisteme» // Sobranie zakonodatel'stva RF. - 2011. - No. 27. - St. 3872.

[11] Konstituciya Rossijskoj Federacii (prinyata vsenarodnym golosovaniem 12.12.1993) (s uchetom popravok, vnesennyh Zakonami RF o popravkah $\mathrm{k}$ Konstitucii RF ot 30.12.2008 No. 6-FKZ, ot 30.12.2008 No. 7-FKZ, ot 05.02.2014 No. 2-FKZ, ot 21.07.2014 No. 11-FKZ) // Sobranie zakonodatel'stva RF. - 2014. No. 31. - St. 4398 .

[12] Postanovlenie Plenuma Verhovnogo Suda RF ot 30.11.2017 No. 48 «O sudebnoj praktike po delam o moshennichestve, prisvoenii i rastrate» // Byulleten' Verhovnogo Suda RF. - No. 2, fevral', 2018. 